\title{
Temperature trend in Bharuch district of Gujarat
}

\author{
K.N. Sondarva, P.S. Jayswal, M.G. Varma and V.A. Patel
}

Article Chronicle : Received : 26.05.2018;

Revised : 01.11.2018; Accepted : 15.11.2018

Key Words : Temperature trend, Rainfall, Climatic parameters directly affecting

\begin{abstract}
Temperature and rainfall are the most variable climatic parameters directly affecting to the agriculture and hydrologic cycle on the earth. Due to changing climate how to cope with the our agricultural produce to survive of human being, it is necessary to determine the effect of changing effect of temperature. So the present study was undertaken with objective of estimating the trend of temperature base on past meteorological data. The results obtained from the data analysis shows that there is significant increase in mean and minimum temperature of winter and summer, the season of summer is slightly shifting to winter as the higher temperature days in increasing in winter season, so in future time it will be necessary grow cold temperature loving plants in very precisely and short duration variety.

HOW TO CITE THIS ARTICLE : Sondarva, K.N., Jayswal, P.S., Varma, M.G. and Patel, V.A. (2018). Temperature trend in Bharuch district of Gujarat. Asian J. Environ. Sci., 13(1\&2): 8-16, DOI: 10.15740/HAS/AJES/13.1and2/ 8-16. Copyright@ 2018: Hind Agri-Horticultural Society.
\end{abstract}

